\title{
THE EFFECTS OF JOB SATISFACTION AND ORGANIZATIONAL COMMITMENT ON ORGANIZATIONAL CITIZENSHIP BEHAVIOR
}

\author{
Arif Partono Prasetio ${ }^{1}$, Syahrizal Siregar ${ }^{2}$, Bachruddin Saleh Luturlean ${ }^{3}$ \\ School of Economic \& Business, Telkom University \\ e-mail: Partono67@gmail.com
}

\begin{abstract}
The service quality is always the main factor for organization which focuses on the customer satisfaction to enhance their business and their performance. In order to have the great quality, they depend on their human resources. They need human resources who perform well. The employee who shows strong Organizational Citizenship Behavior believed can be performs better. That is why it is important for the organization to create employee with the strong OCB. OCB influenced by various factors. $J o b$ satisfaction and organization commitment are two important factors among them, which can predict the OCB. Organization should maintain the level of their employee's satisfaction and commitment in order to develop the strong $O C B$. The research analyzed the effect of the job satisfaction and organization commitment on OCB at the PLN Distribution Office for Wet Java and Banten. Research conducted towards 100participants using the multiple regression and descriptive analysis method.Through the analysis we found that job satisfaction and organization commitment has significance relation toward $O C B(0.516)$. This finding is in line with previous research which promotes positive relation between these variables, eventhough only a mild percentage (0.266).The organization should place detail attention when applying the treatment. We suggest that the both job satisfaction and organization commitment should apply simultaneously in order to get better result. Further research needed to identify others factor which might be important to enhance the OCB.
\end{abstract}

Keywords: Organizational Citizenship Behavior, Job satisfaction, Organizational Commitment, Multiple Regression.

\begin{abstract}
Abstrak
Layanan yang optimal merupakan salah satu kunci keunggulan bersaing. Peran sumberdaya manusia dalam membangun layanan yang unggul sangat penting. Organisasi dirasa perlu untuk membangun dan memiliki sumberdaya manusia yang handal. Di samping kinerja berdasarkan pekerjaan utamanya, karyawan juga diharapkan untuk menunjukkan perilaku positif yang mendukung pencapaian kinerja perusahaan. Karyawan yang memiliki tingkat kewarganegaraan organisasional tinggi biasanya memiliki kinerja formal yang tinggi juga. Hal ini menegaskan pentingnya organisasi membangun semangat kewarganegaraan rganisasional (OCB). Pengembangan perilaku OCB dipengaruhi oleh berbagai faktor, diantaranya kepuasan kerja dan komitmen organisasi. Organisasi perlu membangun kepuasan kerja dan komitmen organisasi karyawan untuk mengembangkan karyawan dengan tingkat OCB yang tinggi. Penelitian ini menganalisis pengaruh kepuasan kerja dan komitmen organisasi terhadap OCB pada karyawan PLN Kantor Distribusi Jawa Barat dan Banten. Penelitian ini menggunakan sampel sebanyak 100responden dan analisisnya menggunakan teknik regresi berganda dan deskriptif analitis. Hasil riset ini menujukkan bahwa kepuasan kerja dan komitmen organisasi secara simultan memiliki pengaruh positif terhadap OCB (0.516). temuan ini sejalan dengan riset terdahulu yang juga menyatakan adanya hubungan pengaruh positif di antara variabel yang digunakan. Hanya saja besarnya pengaruh dari hasil riset ini hanya sebesar (0.266).berdasarkan temuan tersebut, perusahaan perlu menerapkan kebijakan yang berorientasi pada kepuasan kerja karyawan dan yang bisa mendorong terbentuknya komitmen organisasi. Kedua faktor ini sebaiknya digunakan secara bersamaan untuk membangun OCB karyawan. Riset selanjutnya yang membahas OCB bisa menggunakan variabel lain yang bisa saja memiliki pengaruh lebih besar.
\end{abstract}

Kata Kunci: Perilaku Kewarganegaraan Organisasional, Kepuasan Kerja, Komitmen Organisasi, Regresi Berganda. 


\section{INTRODUCTION}

The importance of Organizational Citizenship Behavior (OCB) has attracted a lot of attention in academic research. The research from Cottrill, Lopez, \& Hoffman (2014), Koning \& Van Cleef (2015), Lambert, Hogan, \& Griffin (2008) and Ma, Qu, Wilson, \& Eastman, (2013) discussed OCB from various aspects from the leadership, the staffs, and the customers. It is widely known that employee who has the strong OCB will become more loyal towards their organization. OCB believed can increase the effectiveness of the organization which led to their success. Employees who are felt included in the organization generally will reciprocate with their positive behavior, OCB. In this case, the organization will reap the benefits in the long run. Ma et al. (2013) and Lambert et al. (2008) explain that OCB can promote cost saving, faster job/work completion, and resources optimization. Even though OCB play an important role in the building of employee performance which led to the organizational performance, yet only several organizations put it in their reward system (Chahal \& Mehta, 2010). There are many factors which can drive the OCB of the employee. The research presents two of them which are job satisfaction and organization commitment $(\mathrm{Ng}, 2015$; Yadav \& Rangnekar, 2015).

Job satisfaction and organization commitment have influence towards the OCB. The research from Salehi and Goltash (2011) found that both have positive impact on OCB. Meanwhile, Miao (2011) conducted research on a Chinese state-owned enterprise and reveal that job satisfaction has significant relation on OCB. Chahal and Mehta (2010) stated that there is positive relation between role clarity which is part of job satisfaction with the OCB and organization effectiveness. Meanwhile, Schappee (1998) found that job satisfaction has no significant relationship with OCB. This result parallel with Intaraprasong, Dityen, \& Krugkrunjit (2012) who found that job satisfaction only has low positive relation with OCB. These differences make the study of job satisfaction and its impact toward OCB interesting. Many aspects in the job satisfaction involved in the building of OCB. We can draw the same conclusion for every study. Of course we also have to consider the organization or our research subject.

As for the organization commitment, according to Koning and Van Kleef (2015) it is one of the major factor besides job satisfaction, perceived fairness, leaders support, which influence and contribute to the willingness of employees to perform OCB. Other researchers who also study the relation between commitment and the OCB are Zeinabadi (2010). His research in Iran found the positive relation between commitment and OCB. Ibrahim \&Aslinda (2013), Chaha 1\& Mehta (2010), Liu $\&$ Cohen (2010), Lambert et al. (2008), Bolon (1997) present various result regarding the relation between commitment and the OCB.

The study analyzed the employee's OCB level in PT PLN, Jawa Barat and Banten Distribution Office, which is one of the stateowned enterprises in Indonesia. The uniqueness of this company is that it controls the whole electricity supply in Indonesia. Since they monopolize the service, they used to provide basic service only. But, under the new management, the employee required to work better. In order to provide much better service PLN need qualified human resources who can perform well. Employee can perform well if they show responsibility and integrity. In other word, the organization need employee who are willing to give $100 \%$ of their effort to the customer and willing to contribute more than they should.

They need employees who possess strong OCB. One of the indicators which can point the level of OCB is the attendance record and the employee performance. Based on the attendance record from January 2013 to June 2014 we found there are still high absenteism and tardiness rate. This could indicate the employee still has low OCB level. To support the finding, we conducted the interview with several employees and the HR Supervisor. The supervisor felt that employee yet to show the OCB level which are in line with the expectation. This also related with the performance appraisal result where the number of very potential employee still below the expectation level. However, when we conduct the observation and discuss with some employees, they felt that they have done much for the organization, especially when it comes to helping their coworkers. They are also proud to work for PLN. The phenomenon is interesting to explore. We 
measure the level of job satisfaction, organization commitment, and the OCB. Furthermore, we analyzed whether there is any relation between employee's OCB and job satisfaction and organization commitment.By identifying this, we present knowledge to the organization on how to manage the employee behavior which can turn into organization performance.

\section{LITERATURE REVIEW}

The study regarding relationship between satisfaction, commitment, and organization citizenship can be trace back to the theory of social exchange theory. Based on the works of Homans (1958), interaction between person can be said as an exchange of good, whether material or non material. The social exchange is the actions that are contingent on rewarding reactions from others (Emerson, 1976). It is implied that the relation is two-sided, mutually contingent, and mutually rewarding process, where there are transactions or just exchange. If the individual feel they will gain benefit from what they do, then theu will repeat it. Individu also known to seek maximal gain or minimize their loss.

Lawler and Thye (1999) using concept of self-interes and interdependence when explaining the interaction between individuals. They regards these two as the basic forms of interaction between two or more participants who have something of value to each other. The next step for them is to decide whether to exchange and in what amounts in order to get what they need in a less cost as possible. These kind of interaction usually also takes place on work environment. People at work interact with each other trying to get the best result for the team and for themzelves. When they do the interaction, they often have to bargain or in business we call it negotiation. Driving with the same interest (to maximize their achievement) people will try to gain more than they loss. Often they cannot achieve what they need or want without sacrificing some of their resources. This is where the exchange happen. The same thing applied in therelation between employees and organization they worked for.

Stafford (2008) explain that social exchanges involve a connection with another person, trust,donot have any legal obligations, flexible, rarely involve in explicit bargaining.
This is what we do at work and shaping the relation in it. This is a social research based on the human behavior in the workplace. When we discuss about the satisfaction, commitment, and citizenship behavior, than we will definitely talk about the interaction. Or we can call it social exchange in the work place.

To understand the model, we start this literature review by prividing basic explanation about human resources management, organization behavior, and also explain the variables used in this research. We start with the human resources management which believed to have an important role in order to develop qualified employees (Samad \& Yusuf, 2012). These outstanding employees needed by the organization in order to thrive in the business. Ivancevich(2010) stated that human resources has function such as organizing, developing and enhancing the ability and knowledge, provide and applying motivation techniques which match with the employee's need, promote better quality work-life, enhance job satisfaction, and manage good communication between management and employees.

The HR manager should understand the employee's character so they can act accordingly to each situation. They need to have knowledge about organization behavior. Organization behavior can help organization to focus on how to productivity, maintaining absenteism, turnover, reducing unwanted work-place behavior, and increasing the OCB level (Robbins and Judge (2013). The behavior study can help manager to know and understand his/her people. Without the knowledge they will have difficulties in developing good working relation. The next explanation is about the three variables used in this research; job satisfaction, organization commitment, and OCB.

Uhl-Bien, Schermerhorn, \& Osborn (2014) defined job satisfaction as an attitude which reflect the individual positiveand negative feeling towards their co-workers, jobs, and work environment. Robbins and Judge (2013) explain the job satisfaction as a positive feeling about a job, resulting from an evaluation of its characteristics. It is clear from the definition that job satisfaction is closely related to what employee perceive about their job. Satisfied employees would seem more likely talk positively about the organization, help others, and work beyond the normal expectations in their 
job (Robbins \& Judge, 2013). Meanhile, Luthans (2011) explain the outcome if employee felt satisfy or not; Performance, Turnover, and Absenteism. The discussion reveals the importance of job satisfaction towards organization. To measure the level of job satisfaction we used the JDI approach which used five dimensions; job it-self, supervisor, co-worker relation, salary, and career development (Robbins \& Judge, 2013).

The second independent variable is organization commitment which defined as the degree of loyaltyindividual felt toward the organization (Schermerhorn et al., 2012). The following definition explained by Gibson, Ivancevich, and Donnelly (2012) as a sense of identification, loyalty, and involvement expressed by an employee toward the organization or unit of the organization. Luthans provide more detail explanation about the commitment. He define it as a strong desire to remain a member of a particular organization, support by willingness to exert high levels of effort on behalf of the organization and acceptance of the values and goals of the organization. We can sure view the commitment as an ongoing employee attitude especially their loyalty towards the organization. Regarding the outcome of organization commitment, Schermerhorn et al. (2012) discuss that the individuals with a high organizational commitment will strongly identify themselves with the organization and take pride in considering themselves members. To measure the commitment level, the concept from Meyer \& Allen will be used (1991). They provide three dimensions which are; Affective Commitment, Continuance Commitment, and Normative Commitment.

The dependent variable which is OCB defined by Robbins and Judge (2013) as the discretionary behavior that is not part of an employee's formal job requirements, and that contributes to the psychological and social environment of the workplace. While Schermerhorn et al. (2012) describe OCB as employee's willingness to "go beyond the call of duty" or "go the extra mile" in one's work. Then, Organ (Luthans, 2011) also explain OCB Individual behavior that is discretionary, not directly or explicitly recognized by the formal reward system, and that in the aggregate promotes the effective functioning of the organization. These definitions clearly explain that OCB related with the internal motivation of the employees to act beyond their formal duties. The employee who has high OCB will demonstrate high motivation, they will defend their organization, and they are proud to become its representatives.

In order to measure the OCB in PLN, we use the concept from Organ (Luthans, 2011). He argues there are five dimensions which contribute to the OCB. Altruism (e.g., helping out when a coworker is not feeling well), conscientiousness (e.g., staying late to finish a project), civic virtue (e.g., volunteering for a community program to represent the firm), sportsmanship (e.g., sharing failure of a team project that would have been successful by following the member's advice), courtesy (e.g., being understanding and empathetic even when provoked).

The employee with high or strong OCB will benefit the organization and themselves. That is why the development of practices that can lead to strong OCB considered important in many organizations. No wonder one of the most important functions in human resources is not limited to make people satisfy, but also make them committed and have the strong involvement toward organization.

\section{The link between Job Satisfaction and OCB}

Chahal \& Mehta (2010) conclude that there is positive and significant effect from job satisfaction on OCB. Koning and Van Kleef (2015) supported this notion. This papers emphasis the concept that if the employee's job satisfaction goes up, then the OCB also increasing. Several research which show the results that people who satisfied with their work tend to display higher organizational citizenship behavior are Pavalache-Ilie (2014), Intaraprasong et al.. (2012), Mohammad, Farzana, \& Alias (2011), and Qamar (2012). They concluded that job satisfaction has positive relation with organization commitment. These findings can be referred by the organization to develop a strategy to maintain the satisfaction level of their employees.

\section{The link between Organization Commitment onOCB}

We have this assumption, that the higher the commitment, the stronger the OCB of the employee. This viewpoint is backed by several 
scientific researches. Liu \& Cohen (2013) found the relation between organization commitment and the OCB. Noor (2009) identify the role of the organizational commitment in enhancing the organizational citizenship behavior of the teachers in Pakistan. Noor (2009), Asiedu, Sarfo, and Adjei (2014), Ng \& Feldman (2011), Ibrahim \&Aslinda (2013), and Bakhshi, Sharma, and Kumar (2011) are among the researchers who had the same argument about the positive and significance relation between these variables. Although the research use different viewpoint (some directly related the organization commitment, and some use the detail dimension; affective, cognitive, and normative), the result show the same pattern.

Based on the previous researches concerning the relation between variables, we determine the hypothesis for this research.

$\mathbf{H}_{1 \mathbf{a}}$ : There is positive and significant effect between job satisfactions on OCB.

$\mathbf{H}_{\mathbf{1 b}}$ : There is positive and significant effect between organization commitments on OCB.

$\mathbf{H}_{\mathbf{1 c}}$ : There is positive and significant effect between job satisfaction and organization commitment on OCB.

\section{METHODOLOGY}

This is a quantitative research which goals is to measure the relation between job satisfaction and organization commitment on OCB. The total population for the research is $252 \mathrm{em}$ ployees of PT PLN (Persero) West Java and Banten Distribution Office.Non-probability samplingwas used and combined with the accidental sampling. We recruit the participant from the various jobs in the office. We distributed 150 questionnaires and get the 100 participants who completed the questionnaire. The questionnaire distributed directly to the participants who voluntarily participate. The return the questionnaire between one to three weeks.

The primary data obtain by the selfadministered questionnaires which consist of 45 questions. There are 14 questions for the job satisfaction, 16 for organization commitment, and 14 questions for the OCB.The questionnaire develop using 5 point-scaleLikert model consisting of the lowest point $1=$ very disagree until $5=$ very agree. All questions are already tested for the reliability and validity. The descriptive analysis was used to present the result and to analyze the relation of the variable. The validity and reliability test conducted since the questionnaire is self-administered. The Cronbach's Alpha for the job satisfaction is 0.882, the organization commitment is 0.910 , and for the OCB is 0.875 . These score are all above the required 0.70 .

The descriptive method used to explain the result. The level of the job satisfaction, the organizational commitment, and the OCB in PLN West Java and Banten Distribution Office were identified. We present the result in a percentage and also in real figure. The interpretations conducted by comparingeach of the items result with the optimum result if all respondent choose the highest score. There are five level of interpretation, from the lowest level to the highest level. We also add the information we collected from the observation.

The relation between variables measured using multiple regression analysis. Before conducting the multiple regression analysis we run several test to make sure the data met the requirement for multiple regression analysis. We test the data for normality, heteroscedasticity, and multicolinearity. Normality test used to analyze whether the data set normally distributed or not.

The Kolmogorov-Smirnov test indicate the Asymp Significance for 2 tailed is 0.263 (above the required 0.05) which mean the data normally distributed. The heteroscedasticity test also proved that the data set can be proceeds to the multiple regressions, since it passed the criteria. The significant level at 0.322 for the job satisfaction and 0.167 for the organization commitment mean there is no heteroscedasticity. The last test on multicolinearity also passed. The Tolerance figure should be above 0.1 and the should be under 10 . The test reveals that the Tolerance figure is 0.720 and the VIF 1.389, both matches the requirement. We used the SPSS version 21 to calculate the above calculation. After ensuring that the data set can be used in multiple regression analysis, we then measure the relation between variables.

\section{RESULT AND DISCUSSION}

The result shows that the PLN employees had high job satisfaction $(75.4 \%)$. The highest di- 
mension which contribute to this figure is the relation with their supervisor $(77.47 \%)$, followed by the co-workers dimensions $(76,7 \%)$ and work itself $(76,50 \%)$, then the career development $(76.30 \%)$, and the salary $(75.40 \%)$. From these figure, we can say that while some view the salary is the most important factors in building the job satisfaction, the research prove that people focus on other things. In fact the relations with supervisor hold the highest percentage. This mean, organization should try to improve their leader because the good leader can build the high satisfaction.

The level of the organization commitment dimension is also high; $79.35 \%$ for affective commitment, $71.17 \%$ for the continuance commitment, and $75.87 \%$ for the normative commitment. The result showed that the employees of PLN have high level of commitment. The most interesting part is that the level of affective commitment is the highest. This could mean that the employees feel happy to work in the company and they have high sense of ownership. This is a good condition for the organization if most of the employee feels that way. High commitment employee can lead to a better performance.

The figure of $78.5 \%$ showed that the OCB level in PLN is also high. As shown on the Table 3, the highest subscale is the courtesy. Courtesy mean that someone has open mind and always try to build a good relation to others. Follow by civic virtue which could mean that employees show the responsibility towards their job. Overall, if the OCB is high, employees of the organization tend to do more than they expected. For example; working late without being paid or they talk highly about their organization. These behaviors predicted to affect the performance.

Table 1: Level of Job Satisfaction

\begin{tabular}{lrrr}
\hline \multicolumn{4}{c}{ Job Stisfaction } \\
\hline \multicolumn{1}{c}{ Subscale } & Score & Maximum & \%tage \\
\hline Salary & 754 & 1000 & $75,4 \%$ \\
Career Advancement & 1526 & 2000 & $76,3 \%$ \\
Nature of work & 765 & 1000 & $76,5 \%$ \\
Supervisor & 1162 & 1500 & $77,5 \%$ \\
Co-worker & 1534 & 2000 & $76,7 \%$ \\
\hline \multicolumn{2}{c}{ Average } & & $76,5 \%$ \\
\hline
\end{tabular}

Table 2: Level of Organization Commitment

\begin{tabular}{|c|c|c|c|}
\hline \multicolumn{4}{|c|}{ Organization Commitment } \\
\hline Subscale & Score & Maximum & \%tage \\
\hline Affective & 1587 & 2000 & $79,4 \%$ \\
\hline Continuance & 2135 & 3000 & $71,2 \%$ \\
\hline Normative & 2276 & 3000 & $75,9 \%$ \\
\hline Ave & & & $75,5 \%$ \\
\hline
\end{tabular}

Table 3: Level of OCB

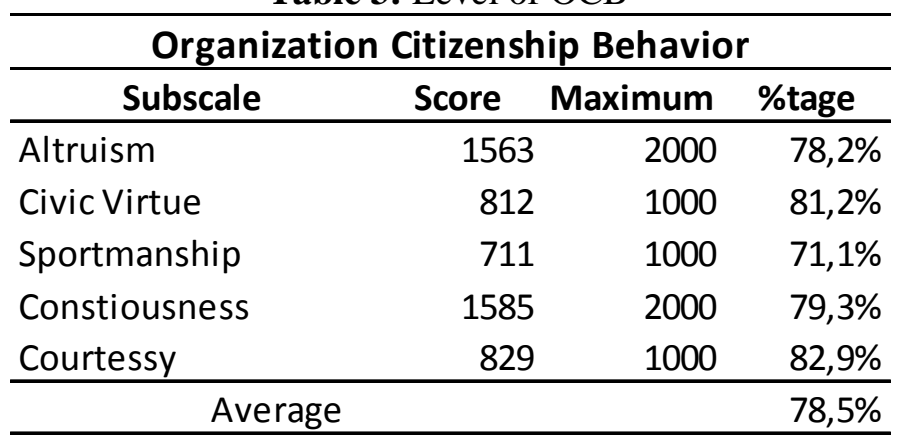


The following discussion focus on how the relation between variables measured and what is the result. We started the discussion from the partial relations between job satisfaction and organization commitment on OCB. The significant figure in Table 4 show both independent variables has significant relation with OCB (Sig. for job satisfaction is 0.001 and for organization commitment is 0.018). This mean job satisfaction and organization commitment can predict the OCB in PLN. The hypothesis $\mathrm{H}_{1 \mathrm{a}}$, 'There is positive and significant effect between job satisfactions toward the OCB' and the $\mathrm{H}_{1 b}$, 'There is positive and significant effect between organization commitment and OCB', both accepted.

If we look at the standard coefficient then we can say the relation between both independent variables is not strong ( 0.342 for job satisfaction and 0.246 for organization commitment). As we know that in order to describe strong relationship, the figure should more than 0.5 or nearer to 1 . This does not mean that these two variables are useless in predicting the OCB, it is just they are not strong enough. There could be other variables which have bigger contribution to build the OCB in PLN.

Now we take a look at the simultaneous relation between job satisfaction and organization commitment on OCB. To describe the simultaneous relation we refer to the Table 5 . The Sig. figure show 0.000 which mean that simultaneously, both variables has relation with OCB. It is also means that the hypothesis $\mathrm{H}_{1 \mathrm{c}}$, 'There is positive and significant effect between job satisfactions and organization commitment on $\mathrm{OCB}^{\prime}$ is accepted.

Table 4: Coefficient

Coefficients $^{a}$

\begin{tabular}{|c|c|c|c|c|c|c|}
\hline \multirow[b]{2}{*}{ Model } & & \multicolumn{2}{|c|}{ Unstandardized Coefficients } & $\begin{array}{l}\text { Standardized } \\
\text { Coefficients }\end{array}$ & \multirow[b]{2}{*}{$t$} & \multirow[b]{2}{*}{ Sig. } \\
\hline & & $\mathrm{B}$ & Std. Error & Beta & & \\
\hline 1 & (Constant) & 1,647 & ,303 & & 5,436 &, 000 \\
\hline & JS & 341 & 102 & ,342 & 3,334 & 001 \\
\hline & $\mathrm{OC}$ & ,230 & 096 & ,246 & 2,400 & 018 \\
\hline
\end{tabular}

Table 5. Anova

ANOVA $^{a}$

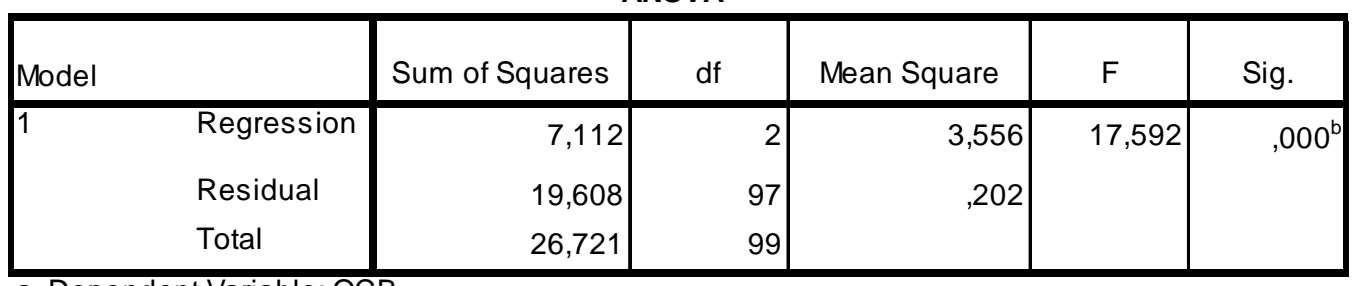

a. Dependent Variable: OCB

b. Predictors: (Constant), OC, JS

Table 6. Model Summary

Model Summary ${ }^{b}$

\begin{tabular}{|l|r|r|r|r|}
\hline Model & $\mathrm{R}$ & \multicolumn{1}{|c|}{ R Square } & $\begin{array}{c}\text { Adjusted } \\
\text { R Square }\end{array}$ & $\begin{array}{c}\text { Std. Error of the } \\
\text { Estimate }\end{array}$ \\
\hline 1 &, $516^{\mathrm{a}}$ &, 266 &, 251 &, 44961 \\
\hline
\end{tabular}

a. Predictors: (Constant), OC, JS

b. Dependent Variable: OCB 
The strength of the relation showed on the Table 6. The multiple regression result show that simultaneously both job satisfaction and organization commitment, if used together will have bigger correlation $(\mathrm{R}=0.516)$. The result correspond to the work of Salehi\&Goltash (2011) and Sajjad et al. (2011). They also found the relationbetween satisfaction and commitment on OCB. This means that both variables have stronger effect if used simultaneously.

Nevertheless, we also need to observe that the R Square for both variables is relatively low (0.266). This means only $26.6 \%$ that the OCB in PLN can be explained by job satisfaction and organization commitment. There might be other variables which have more impact on OCB than these two. These variables should be identifies, and the organization should develop the possible application in work place to build strong OCB from their employees. These other variables can predict $73.4 \%$ of the OCB in PLN. This lead to the importance of conducting further research to identify what is the most important variables to develop higher OCB in PLN. It might be the reward system or career advancement? Or maybe it is just increased salary. The option is abundant therefore researcher should choose it wisely.

\section{CONCLUSION, LIMITATIONS, AND FU- TURE RESEARCH}

This study shows the importance identifying variables which has close relation with OCB. Moreover, it provides evidence on how two mechanisms (satisfaction and commitment) explain the level of OCB. The study shows how the combination of two variables can help understand how employees OCB. So the management can use this for effectively managing performance and well-being in organizations.

The job satisfaction, organization commitment, and OCB in PLN West Java and Banten Distribution Office were found at the high level. Employees satisfy with their job and feel committed that is why their OCB also high. Even though the management felt that the employee still does not show the acceptance level of commitment and OCB. We observed that these differences might be cause by the lack of communication between the employees and the supervisor. Without routine communication it is hard to know what others are doing. We offer a simple solution to improve the level of trust. Management provides employees with clear expectation and employees inform management what they need to do their job better. We found that the co-worker relation is quite smooth.

Job satisfaction and organization commitment proved to be significant in building the OCB. But study in PLN show both has relatively small effect. There are two possibilities. First, the result is true so the organization should identify the aspects which can build stronger OCB. Second, they just need to enhance the relation between management and employees. Both can discuss about what each party needed, then two worked out together to adjust each other need. In this way both party can gain more result.

It is clear that job satisfaction and organization commitment should be used simultaneously in order to get better result. In this case, the organization can seek aspect from these variables which have bigger impact. The result from this survey can be a good starting point. The result can become even better if the human resources department involve and take charge to identify the strongest aspect which can help increasing the OCB.

A part from the management impact, the academic impact from this study is to give a broader view regarding the concept of OCB and its relation with particular variables. We hope this paper can contribute to the study of employee behavior toward their organization. We also realize that this paper only analyze one organization. We will continue our work regarding OCB and other organization behavior aspects using more participants from various industries in West Java and Indonesia.

\section{REFERENCES}

Asiedu, M., Sarfo, J.O., \& Adjei, D. 2014. Organizational commitment and citizenship behavior: tools to improve employee performance, an internal marketing approach. European Scientific Journal. 10(4). 288-305.

Bolon, D.S. 1997. Organizational citizenship behavior among hospital employees: a multidimensional analysis involving job satisfaction and organizational 
commitment. Hospital \& Health Services Administration. 42(2).

Bakhshi, A., Sharma, A.D., \& Kumar, K. 2011. Organizational Commitment as predictor of Organizational Citizenship Behavior. European Journal of Business and Management. 3(4).

Chahal, H., \& Mehta, S. 2010. Antecedents and consequences of organizational citizenship behavior (ocb): a conceptual framework in reference to health care sector. Journal of Services Research. 10(2). 24-44.

Cottrill, K., Lopez, P.D., \& Hoffman, C.C. 2014. How authentic leadership and inclusionbenefit organizations. Equality, Diversity and Inclusion: An International Journal. 33(3). 275-292..

Emerson, R.M., 1976. Social Exchange Theory. Annual Review of Sociology. 21(1). 335-362.

Gibson, J.L., Ivancevich, J.M., Donnelly Jr., J.H., \& Konopaske, R. 2012. Organizations: Behavior, Structure, Processes, 14th edition. New York: McGraw-Hill.

Homans, G.C. 1958. Social behavior as exchange source. American Journal of Sociology. 63(6). 597-606.

Intaraprasong, B., Dityen, W., \& Krugkrunjit, P.T. 2012. Job satisfaction and organizational citizenship behavior of personnel at one university hospital in Thailand. Journal Med Assoc Thai. 95(6). 102-108.

Ibrahim, M.A., \& Aslinda, A. 2013. Relationship between organizational commitment and organizational citizenship behavior (ocb) at government-owned corporation companies. Journal of Public Administration and Governance. 3(3). 35-42.

Ivancevich, John M. 2010. Human Resource Management $\left(11^{\text {th }} \mathrm{ed}\right) .1221$ Avenue of The Americas, New York, NY 10020: McGraw Hill/ Irwin.

Koning, L.F., \& Van Kleef, G.A. 2015. Howleaders' emotional displays shape followers' organizational citizenship be- havior. The Leadership Quarterly. 26. 489-501.

Lambert, Eric G., Hogan, Nancy L., and Griffin, Marie L. 2008. Being the good soldier, organizational citizenship behavior and commitment among correctional staff. Criminal Justice and Behavior, Vol 35, No. 1, pp. 56-68.

Lawler, Edward J., \& Thye, Shane R. 1999. Bringing Emotions Into Social Exchange Theory. Annu. Rev. Sociol, Vol. 25 , pp. 217-244.

Liu, Y. \& Cohen, A. 2010. Values, commitment, and OCB among Chinese employees. International Journal of Intercultural Relations, Vol. 34, pp. 493506.

Luthans, Fred. 2011. Organizational Behavior: An Evidence- Based Approach $\left(12^{\text {th }} \mathrm{ed}\right) .1221$ Avenue of The Americas, New York, NY 10020: McGraw Hill/ Irwin

Ma, Emily Ma, Qu, Hailin., Wilson, Marie., and Eastman, Ken. 2013. Modeling OCB for Hotels: Don't Forget the Customers. Cornell Hospitality Quarterly, Vol. 54, No. 3, pp. 308-317.

Meyer, J.P. \& Allen, N.J. 1991. A ThreeComponent Conceptualization of Organizational Commitment. Human Resource Management Review. Vol.1, No. 1, hlm. 61-89.

Mohammad, J., Habib, Farzana Q. dan Alias, M.A. 2011. Job Satisfaction and Organization Citizenship Behavior: An Empirical Study at Higher Learning Institutions. Asian Academy of Management Journal, Vol. 16, No. 2, hlm.149165.

Miao, Ren-Tao. 2011. Perceived Organizational Support, Job Satisfaction, Task Performance and Organizational Citizenship Behavior in China - Institute of Behavior and Applied Management, 105-127.

Ng, T.W.H. 2015. The incremental validy of organizational commitment, organizational trust, and organizational identifi- 
cation. Journal of Vocational Behavior. 88. 154-163.

Ng, T.W.H. \& Feldman, D.C. 2011. Affective organizational commitment and citizenship behavior: Linear and nonlinear moderating effects of organizational tenure. Journal of Vocational Behavior, Vol. 79, 528-537.

Noor, Ayesha. 2009. Examining Organizational Citizenship Behavior as The Outcome of Organizational Commitment: A Study of Universities Teachers in Pakistan. Proceedings 2nd CBRC, Lahore, Pakistan November 14.

Pavalache-Iliea, Mariela. 2014. Organizational citizenship behaviour, work satisfaction and employees' personality. Pocedia - Social and Behavioral Sciences 127 ( 2014 ) $489-493$

Qamar, N. 2012. Job Satisfaction and Organizational Commitment as Antecedents of Organizational Citizenship Behavior (OCB).Interdisciplinary Journal of Contemporary Research in Business. Vol. 4 No. 7, 103-122.

Robbins, Stephen P., Judge, Timothy A. 2013. Organizational Behavior $\left(15^{\text {th }}\right.$ ed). One Lake Street, Upper Saddle River, New Jersey 07458: Pearson Education Inc.

Sajjad, N., Noruzy, A., Azar, H.K., NazariShirkouhi, S., \&Dalvand, M.R. 2011. Investigating the relationship between organizational justice, psychological empowerment, job satisfaction, organizational commitment and organizational citizenship behavior: An empirical model.African Journal of Business Management, Vol. 5 No. 13 pp. 5241 5248.

Skehi, Moslem \&Gholtash, Abbas. 2011. The relationship between job satisfaction, job burnout and organizational commitment with the organizational citizenship behavior among members of faculty in the Islamic Azad University -first district branches, in order to provide the appropriate model. Procedia
Social and Behavioral Sciences. Vol. 15, pp. 306-310.

Schappe, Stephen P. 1998. The Influence of Job Satisfaction, Organizational Commitment, and Fairness Perceptions on Organizational Citizenship Behavior. The Journnl of Psychology, Vol. 132, No. 3, pp. 277-290.

Samad, S., \& Yusuf, Salma Y.M. 2012.The Role of Organizational Commitment in Mediating the Relationship between Job Satisfaction and Turnover Intention. European Journal of Social Sciences, ISSN 1450-2267 Vol.30, No.1, hlm.125-135.

Schermerhorn, Jr. J. R., Osborn, R.N., UhlBien, M., Hunt, J.G. 2012. Organizational Behavior, $12^{\text {th }}$ edition. New Jersey: John Wiley \& Sons.

Stafford, L. 2008. Social exchange theories: Calculating the rewards and costs of personal relationships. In L. Baxter, \& D. Braithwaite (Eds.), Engaging theories in interpersonal communication: Multiple perspectives. (pp. 377-391). Thousand Oaks, CA: SAGE Publications, Inc. doi: http://dx.doi.org/10.4135/97814833295 29.n28.

Uhl-Bien, Mary, Schermerhorn, Jr., John R., Osborn, Richard N. 2014. Organizational Behavior, Experience Grow Contribute $\left(13^{\text {th }}\right.$ ed). 222 Rosewood Drive, Danvers, MA 01923: Clearance Center, Inc

Yadav, M., \& Rangnekar, S. 2015. Supervisory support and organizational citizenship behavior: mediating role of participation in decision making and job satisfaction. Evidence-based HRM. 3(3). 258-278.

Zeinabadi, Hassanreza 2010. Job Satisfaction and Organizational Commitment as Antecedents of Organizational Citizenship Behavior (OCB) of Teachers Procedia Social and Behavioral Sciences, 5, 988-1003. 